\title{
Three new species of Indigofera (Fabaceae: Faboideae) from Cape York Peninsula
}

\author{
Peter G. Wilson ${ }^{1}$ and Ross Rowe ${ }^{1,2}$
}

\begin{abstract}
${ }^{1}$ National Herbarium of New South Wales, Royal Botanic Gardens, Sydney NSW 2000, Australia ${ }^{2}$ present address: Department of the Environment, Water, Heritage and the Arts, GPO Box 787, Canberra ACT 2601, Australia.
\end{abstract}

\begin{abstract}
Three new species of Indigofera are described: Indigofera elachantha Peter G. Wilson \& Rowe, a species related to $I$. pratensis but distinguished by its slender inflorescence axis and rather small flowers, Indigofera polyclada Peter G. Wilson \& Rowe, distinguished by its semi-prostrate multi-stemmed habit and very sparse indumentum; and Indigofera wannanii Peter G. Wilson, a recently discovered species with probable affinities to $I$. bancroftii and $I$. tryonii. All species are illustrated and their conservation status discussed.
\end{abstract}

\section{Introduction}

To date, there have been only two named endemic species of the genus Indigofera in that portion of Cape York Peninsula north of Laura. These are Indigofera pratensis, a species with a range that stretches from just north of Brisbane to the Portland Roads/Weipa area, and I. polygaloides, a poorly known species with collections from scattered localities across northern Australia (Wilson \& Rowe 1994). Bailey (1900), in his Queensland Flora, suggested that I. saxicola F. Muell. also occurred in Queensland, in the 'Gulf Country' but did not indicate any particular collection. However, I. saxicola was originally described from the Northern Territory and no specimen from Bailey's time can be found in the Queensland Herbarium bearing this name. It now seems very likely that Bailey's inclusion of this species was based on information received from Mueller. In the Melbourne Herbarium, there are a number of specimens collected by Stephen Johnson from "Stuarts River" (=Stewart River, south of Coen) in 1891 on which Mueller has written 'saxicola' in pencil on the labels. Subsequently, this name has been applied to a few specimens from Cape York that show similarities to I. pratensis but have more rounded leaves and smaller flowers, characters that make these plants somewhat reminiscent of I. saxicola. In a hand-written note attached to one specimen (MEL 584598), Mueller has noted a further distinctive characteristic of this plant, viz. "fruit not deflexed". This species is here named I. elachantha.

The two other new Cape York species described here are currently known from only one or two locations. Both are low-growing subshrubs that have slender stems arising from an underground rootstock. With this habit, both species could easily be overlooked and the above-ground parts might disappear during the dry season, particularly if there had 
been local burning. These two species differ markedly from each other in flower size and indumentum and are described below as I. polyclada and I. wannanii.

\section{Indigofera elachantha Peter G. Wilson \& Rowe, sp. nov.}

Indigofera pratense affinis sed axibus inflorescentiarum tenuioribus, floribus multo minoribus, foliolis plus minusve late ellipticis, fructibus ascendentibus differt.

Holotype: Queensland: Cook: $25 \mathrm{~km}$ north of Duck Holes Creek on the Peninsula Developmental Road (14¹3'S, 1431'ㄹ), J.R. Clarkson 8940 \& V.J. Neldner, 17 Apr 1991 (NSW). Isotypes: BRI, DNA, K, L, MBA, PERTH (all n.v.).

I. saxicola auct. non F. Muell., F.M. Bailey, Qld Flora 2: 388 (1900)

Erect shrub, 1-1.5 m high; young stems ridged, dark brown (young foliage grey-green), strigose with dense, appressed to shortly spreading, equally biramous hairs. Leaves pinnate, with (5-)7-13 leaflets; stipules narrowly triangular, 1.7-4.2 mm long, pubescent, not spinescent, not persistent; petiole 2.5-7 mm long; rachis furrowed, multicellular hairs between leaflet pairs sparse to dense, conspicuous or inconspicuous, red or brown, clubshaped. Leaflets opposite; stipellae conspicuous, $0.5-1.2 \mathrm{~mm}$ long; lamina elliptical to obovate, 10-34 mm long, 6-23 mm wide; upper surface green, with sparse, appressed hairs; lower surface grey-green (paler than above), with sparse, appressed hairs; apex apiculate; veins slightly prominent above and not prominent below. Inflorescences 45-165 mm long, longer than leaves; peduncle 5-22 mm long; bracts triangular, 0.9$1.5 \mathrm{~mm}$ long; flowers pink to purple; pedicel 1.3-2.5 mm long. Calyx 1.4-2 mm long, with subequal lobes less than the length of the tube, clothed with sparse to moderately dense, hyaline, white to brown, appressed hairs. Standard pale pink, broadly obovate to ovate, 4.2-5.5 mm high, 3-4.5 mm wide. Wings oblong to spathulate, 4.2-5.5 mm long, 1-1.5 $\mathrm{mm}$ wide. Keel $4.5-5.7 \mathrm{~mm}$ long, $0.8-1.8 \mathrm{~mm}$ deep; apex acute to rounded; lateral pockets 1.1-1.5 mm long; hairs moderately dense, along the bottom. Staminal tube 3.1-4.5 mm long, colourless. Ovary glabrous. Pod ascending, terete, 25-46 mm long, 2.5-4 mm deep, dark brown or grey, glabrous; apex pointed or shortly beaked; endocarp spotted. Seed 5-7 per fruit. (Fig. 1).

Notes: this species is a member of the I. pratensis group and is most similar to I. saxicola. It differs from the latter by the glabrous ovary and fruit, the \pm rounded (as opposed to distinctly pointed) bud, and the very slender inflorescence axis. It is readily distinguished from I. pratensis by the much smaller flowers (keel $<7 \mathrm{~mm}$ long cf. 10-14 mm). It differs from both by the ascending fruits. Specimens have been collected at only a small number of scattered sites and show some, perhaps significant, geographic variation. Northern collections (from the Pascoe River area) have 9-11 or more leaflets while southern collections (from between Coen and the Palmer River) consistently have 5-7 leaflets. We did consider separating these as subspecies but the floral and inflorescence characters are so distinctive that we have refrained from recognising subspecies pending further collections. There is a single specimen, the only one to have been collected from between Wenlock and Coen $\left(13-14^{\circ} \mathrm{S}\right)$, that has 7-9 leaflets; this area should be investigated further.

The epithet is derived from the Greek elachos, small or short, and anthos, flower.

Distribution and habitat: Queensland; known from scattered sites in Cape York between Hann Creek and south of the Palmer River (c.1230' $\left.-16^{\circ} 30^{\prime} \mathrm{S}\right)$. It is recorded from rocky or sandy soil in Leptospermum scrub or open eucalypt woodland. 


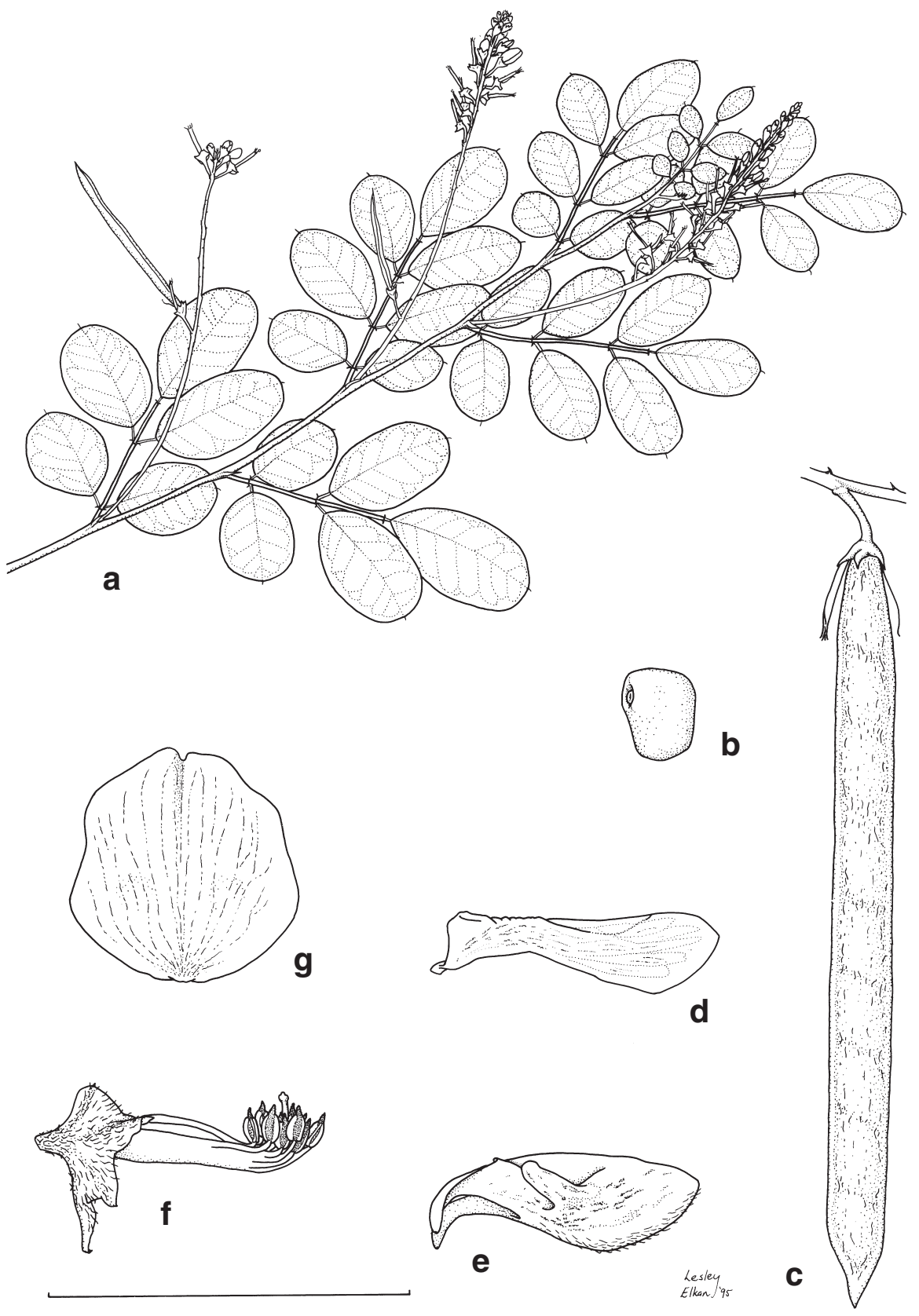

Fig. 1. Indigofera elachantha. a, habit; b, seed; c, fruit; d, wing; e, keel; f, lateral view of calyx and androecium; g, standard. (a, c from Clarkson 8940 \& Neldner, b, d-g from Clarkson 6657\& McDonald). Scale bar: $\mathrm{a}=50 \mathrm{~mm} ; \mathrm{b}=10 \mathrm{~mm} ; \mathrm{c}=20 \mathrm{~mm}$; $\mathrm{d}-\mathrm{g}=7.5 \mathrm{~mm}$. 
Conservation status: this species is reportedly common at many sites (B. Wannan pers. comm.) and does not appear to be at risk; and is assessed as "least concern" using IUCN criteria (B. Wannan pers. comm.).

Selected specimens: Queensland: Cook: near Nelson Creek, Jacky Jacky Range, Wannan 3681 \& Wardrop, 18 Jul 2004 (BRI, NSW); 1 km N of Maloneys Springs, Forster 5288, 19 Jun 1989 (BRI, MO); Head of Hann Creek, 46.5 km from Moreton Telegraph Station, Forster 4560, 27 Jun 1988 (BRI, MEL); Brown's Creek, Pascoe River, Brass 19176, 13 Jun 1948 (CANB, BRI); Flinders Island, Smyth s.n., 1978-1980 (BRI); Stuarts [Stewart] River, Johnson s.n., 1891 (MEL); c. 15 km W of Coen, Clarkson $10130 \&$ Neldner, 31 Jul 1993 (NSW); 19 km S of the Palmer River crossing on the Peninsula Development Rd, 1 km N of the Mareeba-Cook shire boundary, Clarkson 6657 \& McDonald, 4 Mar 1987 (BRI, NSW).

Indigofera polyclada Peter G. Wilson \& Rowe, sp. nov.

Indigofera pratense fortasse affinis sed caulibus laxis pergracilibusque, foliolis minoribus et inflorescentiis multo brevioribus differt.

Holotype: Queensland: Cook: east of Weipa on the Peninsula Development Road, B.S. Wannan 1589 \& R.L. Jago, 24 Feb 2000 (NSW). Isotype: BRI.

Spreading to prostrate subshrub, with woody rootstock; young stems terete, green to brown, glabrous or strigose with sparse, appressed, equally biramous hairs. Leaves pinnate, (9-)13-19(-21) leaflets; stipules linear to subulate, 2-3 mm long, glabrescent, not spinescent, not persistent; petiole $1.5-3.5 \mathrm{~mm}$ long; rachis furrowed, multicellular hairs between leaflet pairs few or absent. Leaflets opposite or sometimes subopposite; stipellae slender, $0.2-1.2 \mathrm{~mm}$ long; lamina elliptical to obovate, (3.5-)5-10 $\mathrm{mm}$ long, 1.5-4 mm wide; upper surface green, glabrous; lower surface green, with sparse, appressed hairs; apex apiculate, $0.3-0.5 \mathrm{~mm}$ long; midrib impressed above and prominent below; other venation reticulate or obscure. Inflorescences 15-25 mm long, shorter than to equal to leaf; peduncle 10-17 mm long; bracts narrowly triangular, $0.5-0.7 \mathrm{~mm}$ long; flowers probably pink to purplish; pedicel $0.8-1.5 \mathrm{~mm}$ long. Calyx 1.2-1.4 mm long, with subequal lobes slightly shorter than the length of the tube, clothed with sparse to moderately dense hyaline appressed hairs. Standard suborbicular, $3.8-4.3 \mathrm{~mm}$ high, 3.6-4.0 mm wide. Wings spathulate, c. $4.5 \mathrm{~mm}$ long, $2 \mathrm{~mm}$ wide. Keel c. $5 \mathrm{~mm}$ long, $1.5 \mathrm{~mm}$ deep; apex acute; lateral pockets c. $0.5 \mathrm{~mm}$ long; hairs sparse, hyaline, at the tip. Staminal tube $2.5-3.5 \mathrm{~mm}$ long, colourless. Pod ascending to spreading, terete, (17-)20-27 mm long, 2-3 mm deep, brown, glabrous or glabrescent; hairs sparse, appressed; apex pointed or shortly beaked; endocarp very faintly spotted. Seed (4-)6 per fruit. (Fig. 2).

Notes: known only from two collections. The slender, loose, multi-stemmed habit of this species differs dramatically from any other Australian species. Its relationships are unclear; it shows some similarities to the I. pratensis group but it differs from all members of this group by its relatively short inflorescences, the non-angular stems and the glabrous adaxial surfaces of the leaves. In these latter features it approaches the I. australis group where it most closely resembles I. baileyi in habit.

The epithet, derived from the Greek, refers to the numerous stems arising from the underground rootstock.

Distribution and habitat: only known from central Cape York where it is reported from open eucalypt (Corymbia hylandii) woodland on yellow earth with ironstone gravels. 
Conservation status: the habit of the plant suggests that it would be unaffected by fire as it is likely to die back to the rootstock in the dry season and resprout and flower in response to summer rain. However, fire frequency could have an impact on breeding success if fruit set and recruitment from seed were affected. While threat levels from occasional fire might be low, the paucity of records suggests that, following IUCN criteria, this species should perhaps be regarded as endangered until further field surveys can be conducted. Its potential habitat has been modelled based on geology and, so far, preliminary searches have failed to find the species at other than the two known locations (B. Wannan pers. comm.).

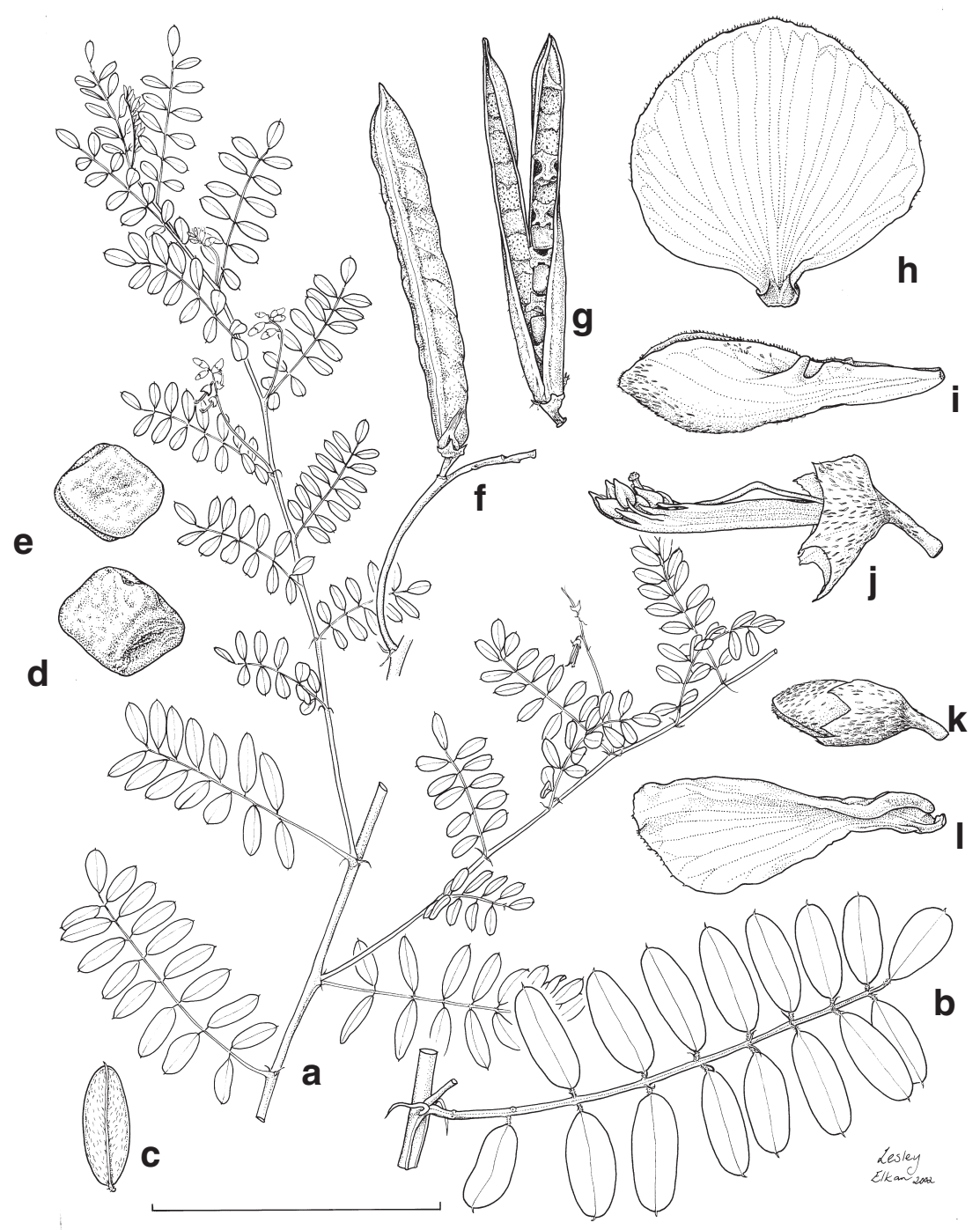

Fig. 2. Indigofera polyclada. a, habit; b, leaf; c, leaflet (abaxial view); d, e, seed; f, g, fruit; $\mathbf{h}$, standard; $\mathbf{i}$, keel; $\mathbf{j}$, lateral view of calyx and androecium; $\mathbf{k}$, bud; $\mathbf{l}$, wing. (a-c, h-l from Wannan 1589 \& Jago; d-g from Clarkson 8500 \& Neldner). Scale bar: a $=40 \mathrm{~mm}$; b-c, f-g $=20 \mathrm{~mm}$; $\mathrm{d}-\mathrm{e}, \mathrm{h}-\mathrm{l}=5 \mathrm{~mm}$. 
Other specimen examined: Queensland: Cook: $4.3 \mathrm{~km} \mathrm{~S}$ of the Wenlock River on the Peninsula Development Road, Clarkson 8500 \& Neldner, 22 Apr 1990 (BRI, NSW, K).

\section{Indigofera wannanii Peter G. Wilson, sp. nov.}

Indigofera tryonii persimilis sed foliolis maioribus non valde discoloribus, fructibus longioribus differt.

Holotype: Queensland: Cook: East of Musgrave on road to Marina Plains (14²45'04"S, 143³3'57"E), B.S. Wannan 4685 \& J. Beasley, 6 Mar 2007 (NSW). Isotypes: BRI, CANB, CNS, K, MEL, MO, US.

Prostrate subshrub to $0.1 \mathrm{~m}$ high, with woody rootstock; young stems angular, somewhat flexuose, green to greyish, tomentose with moderately dense, hyaline to greyish, spreading, \pm equally biramous hairs. Leaves pinnate, (15-)19-29 leaflets; stipules subulate, (2-)2.54.5(-5) $\mathrm{mm}$ long, pubescent, not spinescent, semi-persistent; petiole 1.5-4.5(-8) $\mathrm{mm}$ long; rachis furrowed, multicellular hairs between leaflet pairs dense, conspicuous, red to dark brown, club-shaped. Leaflets opposite; stipellae absent or inconspicuous, to $0.6 \mathrm{~mm}$ long; lamina oblong to narrowly elliptical or elliptical, 8.5-17 mm long, 2.2-6 mm wide; upper surface green, with moderately dense, appressed hairs; lower surface pale green, with moderately dense, appressed to shortly spreading hairs; apex apiculate; reticulate veins usually conspicuous adaxially. Inflorescences 55-100 mm long, a little longer than the leaves; peduncle 20-50 mm long; bracts narrowly triangular to linear, $0.6-1 \mathrm{~mm}$ long; flowers pink-purple; pedicel $0.7-1 \mathrm{~mm}$ long. Calyx 1-2 mm long, with unequal lobes, less than the length of the tube, clothed with moderately dense to dense, hyaline to white, shortly spreading hairs. Standard deep pink to purplish, elliptical to obovate, $8.2-9.5 \mathrm{~mm}$ high, 5-6.5 mm wide; hairs moderately dense, hyaline to yellowish; apex obtuse with a short apiculum. Wings deep purplish pink, oblong, to $7 \mathrm{~mm}$ long, $2 \mathrm{~mm}$ wide. Keel 7-8.8 $\mathrm{mm}$ long, 2.2-2.5 mm deep; apex acute; lateral pockets 1-1.4 mm long; hairs moderately dense, hyaline, at the tip and along the bottom. Staminal tube 6-7 $\mathrm{mm}$ long, pigmented (particularly on the adaxial side). Ovary moderately to densely hairy. Pod descending to deflexed, cylindrical, 23-39 $\mathrm{mm}$ long, 2-3(-4) $\mathrm{mm}$ deep, brown, tomentose; hairs moderately dense, appressed to shortly spreading; apex beaked; endocarp spotted. Seed (4-)6-8 per fruit. (Fig. 3).

Notes: in its \pm prostrate habit, this species most closely resembles $I$. tryonii but differs from it in its larger leaflets that are not strongly discolorous, and in the longer fruit.

This species is named for the author's friend and colleague, Bruce Wannan, who discovered it.

Distribution and habitat: only known from the type locality where it occurs in open eucalypt (Eucalyptus tetrodonta, E. cullenii, Corymbia hylandii, C. nesophila) and Erythrophleum woodland on substrates derived from metamorphic rocks.

Conservation status: this species also has a perennial rootstock so the impact of fire would be much the same as for I. polyclada. However, since the single known locality is threatened by gravel extraction, this species is provisionally assessed, following IUCN criteria, as critically endangered until a more thorough survey can be carried out. This species' potential distribution has likewise been modelled based on geology but has not as yet been located at other sites (B. Wannan pers. comm.). 


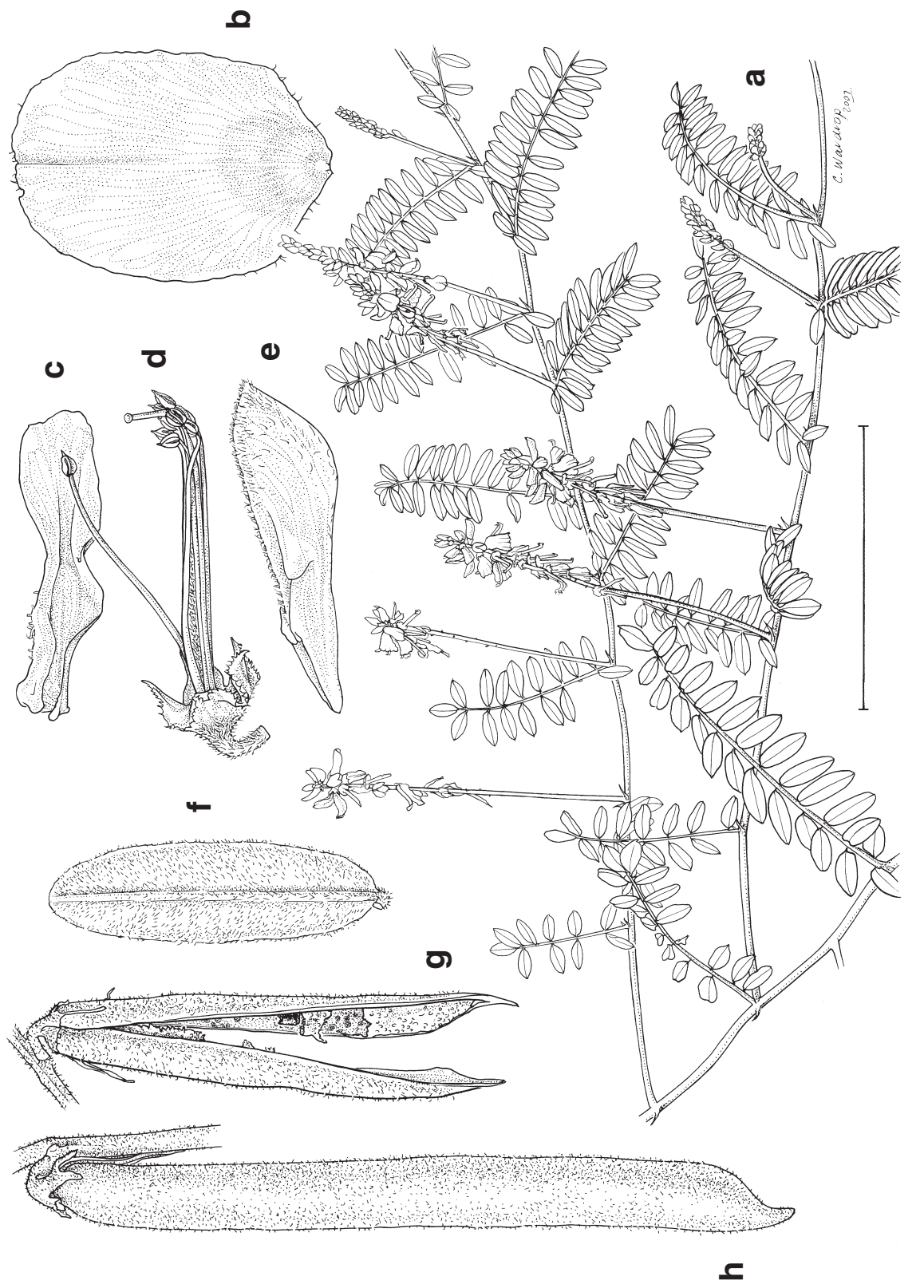

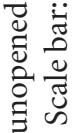

है के ชิ कo 사

巡 ह 
Other specimens examined: Queensland: Cook: East of Musgrave, Wannan $3595 \&$ Graham, 4 Jun 2004 (BRI, CANB, NSW); East of Musgrave, beside road to Marina Plains, Wannan 4512 \& Graham, 17 Jun 2006 (BRI, NSW).

\section{Acknowledgments}

We are particularly grateful to Bruce Wannan, Queensland Environmental Protection Agency, for the gift of specimens, photographs and supplementary information. We also thank John Clarkson and Paul Gadek for assistance in the field or gift of specimens. Special thanks to the illustrators, Lesley Elkan \& Catherine Wardrop, for their excellent work. This research was supported, in part, by an ABRS grant.

\section{References}

Bailey FM (1900) Indigofera. Pp. 384-390 in The Queensland Flora, vol. 2. (Government Printer: Brisbane).

Wilson PG \& Rowe R (1994) The Indigofera trita complex (Fabaceae: Indigofereae) in Australia. Telopea 5: 637-645.

Manuscript received 09 January 2008. accepted 23 June 2008 